UDC 378.14

\title{
THE EUROPEAN UNION EXPERIENCE REGARDING THE EDUCATION POLICY FOR INTERCULTURAL CITY DEVELOPMENT
}

Yu.M. Petrushenko, Dr of Economics, Professor;

T.A. Vasilyeva, Dr of Economics, Professor;

H.O. Shvindina*, P.D., Associate Professor;

T.M. Mayboroda, Assistant;

K.O. Zaichyk, Student

* Sumy State University,

2 Rymskogo-Korsakova Str., Sumy, 40007, Ukraine

Management Department

e-mail: shvindina@management.sumdu.edu.ua

The article analyzes the trends of the European Union's education policy in the field of intercultural dialogue and intercultural development. The chronology of the intercultural education, the transformation of the terms interculturalism is presented, the main legislative acts of the Council of Europe, European conventions, UNESCO documents are analyzed. The basic principles of intercultural education, which form the basis for the development of appropriate education policies, are summarized. The paper proposes the next stage of the interculturalism evolution - the intercultural cities network movement. Sumy city has joined the network but there is a new stage of intercultural education is needed.

Keywords: intercultural dialogue, education policy, Council of Europe, intercultural urban development, intercultural education, intercultural cities network.

DOI: $10.21272 / 1817-9215.2019 .1-20$

\section{INTRODUCTION}

The current demographic situation in Ukraine is characterized by depopulation or loss of population (Shvindina, 2016), since the number of births does not outweigh the mortality rate and, moreover, taking into account the rate of labour migration, the loss from population decline becomes more noticeable. Given the decrease in industry and small businesses, there is a relevant issue not to attract large investors but to develop active small and medium-sized businesses at the expense of migrants who have chosen Ukraine for their residency and, accordingly, professional growth.

The problem of migration for Ukraine is not as acute as for Europe, where intolerance appears very often. At the same time, Ukraine has recently joined the migration processes and is undergoing transformations similar to those that have already taken place in the countries abroad.

The study of European trends lets not only to trace possible scenarios for the development of socio-economic systems but also to reproduce optimistic ones, to choose the best path to a balanced development of society.

The Council of Europe identifies the intercultural dialogue as "as an open and respectful exchange of views between individuals, groups with different ethnic, cultural, religious and linguistic backgrounds and heritage on the basis of mutual understanding and respect " (Council of Europe (2008), which is the basis to build an open and successful society. It is possible to build a system in which intercultural dialogue becomes the norm only with the proper education at different levels of society.

\section{PROBLEM STATEMENT}

The aim of the study is to identify trends in European education policy that have become the basis for urban intercultural development and which are the basis for developing appropriate local strategies through education. 


\section{THE RESULTS OF THE STUDY}

The cultural diversity is the phenomenon that has been experienced in Europe for centuries, but the last six decades starting from 1954 are the most fruitful in terms of agenda, legislations, conventions and memos. The Council of Europe has long been active in the field of education for democratic citizenship and intercultural dialogue. The European Cultural Convention first came into force in 1954. When memories of the war were remembered by people across the continent, and the new redistribution of the world was still going on, European countries agreed that they would encourage the study of languages, history and civilization for the sake of unity.

Today, European countries are facing challenges that require greater support from the Organization at the local level. Migration growth, increasing diversity, the surge in information technology and globalization processes have a significant impact on people. More often there are people who, while living side by side, have completely different beliefs, backgrounds and worldviews. Such diversity in European societies is welcome, but at the same time, it drives to think seriously about how we develop common values that must unite people, how to prevent the collision of different worldviews, which attitudes and behaviors are worth of adaptation.

The European values are supported by a viable framework of conventions and agreements, as well as recommendations, declarations and acts. For instance, chronologically it's fair to start with European Convention on Human Rights that was drafted in 1950 and entered in force in 1953. It's worth of mention that Protocol No 12 of the same document argues general prohibition of discrimination, as it follows, "the enjoyment of any right set forth by law shall be secured without discrimination on any ground such as sex, race, colour, language, religion, political or other opinion, national or social origin, association with a national minority, property, birth or other status" (European Convention, 2013 : 51). Another document is "European Convention on the Legal Status of Migrant Workers" was appeared in 1977 and emphasized that migrant workers should be treated equally as well as other nations .

In 2008, two documents were published at once - the Green Paper on Migration and Mobility (European Union, 2008) and the White Paper on Intercultural Dialogue (Council of Europe, 2008). According to the research (European Union, 2008), migrants have lower achievements in education than their peers, the second generation of migrants has lower marks than the first generation. Challenges to maintain the heritage of different cultures without socio-economic losses due to non-inclusion in the dominant culture caused the emergence of many projects, advocacy in the education system. One of the big components of the White Paper (Council of Europe, 2008) is the embedded research on the historical background of the intercultural dialogue. More than ten main conventions and declaration were analyzed in order to present the evolution of the development of the strategies of dealing with cultural diversity, ensuring the social cohesion and encouraging the intercultural development through the dialogue. There is a number of programs by Council of Europe were analyzed through the lens of the influence of mentioned advocacy and action programmers. The cooperation with the different countries and intergovernmental organization became a core element in a policy that promotes tolerance, respect for human rights and mutual respect for human dignity.

Several reasons can be named to protect the intercultural movement. From the humanist point, the human rights protection guarantees all the participants approximately equal opportunities to grow and rewards the integration of the people. The same thought was expressed by Tucker J.A. (2015) who claimed that freedom to improve one's life pushes a person to deal with the best professionals in the field without concerning their origin. In his opinion, “...gradually under these conditions, the primitive and tribalist ethos begins to subside" (Tucker, 2015).

Human right protection as a basis for intercultural development has its rational explanation. Referring to the seminal experiment by Kurt Lewin (Adelman, 1993), we argue that dictatorship leads to mass production of the middle-quality products, while democracy 
brings a less but significant amount of high-quality goods. This suggestion comes from the results of Kurt's experiment among the kids and teenagers and can't be the universal explanation, but it gives an insight for the understanding, why intercultural dialogue is important, and what the risks of avoiding it.

Continuing to argue for the rationality of intercultural dialogue, we should recall these two main tendencies of expansion strategy known in the history - war or trade. And when we are talking about the trading and setting institutions of trade and exchange for mutual benefits, we are talking about learning of intercultural competences, first of all. And, secondly, learning is a two-way process, and therefore, the freedom and human rights protection play the role of reconciliation of the differences among people towards a finding of the source of wealth for several parties, by enriching each other with the heritage gained independently. The same logic is used by corporate companies in late 80-ties when the decision-making system was enriched by the synergy of different business-unites that played as independent players in the external market, and over time it became wide-spread portfolio management model (Ansoff \& Leontiades, 1976). It took a while for the realization that solution for the society development is based on a combination of heterogeneity and homogeneity. The successful intercultural dialogue requires open-mindedness and capacity to learn from each other with the recognition of the arguments of others, thinking critically but friendly. It facilitates the development of the best ideas for co-existence, co-invention and cooperation towards better living for everyone.

And sustained living together within the framework of democratic citizenship is possible under conditions of education for intercultural competence when the vision of sustainable democratic societies is shared by the participants. In multicultural societies this competence became a crucial one, and as the experts on intercultural education argue (Brotto et al., 2012), "intercultural education can no longer be regarded as a mere add-on to the curriculum in occasional projects, but it must extend, and eventually replace, the monocultural, monolingual setting of our schools and lead to a change of mindset in traditional education"' (Brotto et al., 2012 : 14).

In his works, Barrett (Barrett, 2013; Barrett et al., 2014) mentioned the concept of intercultural competence as a combination of attitudes, knowledge, understanding, skills that enable to understand and respect people from different cultures, other than their own, to respond effectively and with respect the process of interaction and communication with people, establish positive and constructive relationships with people of different cultures etc. It is possible to gain such competence in the intercultural education process.

One should consider the history of multicultural pedagogy as an element of multicultural and subsequently intercultural strategy. The researcher Portera in her work (Portera, 2008) outlines historical prerequisites and step-by-step changes in Council of Europe policy since the 1970s. The timeline of the events, starting with the first resolution in 1970, is presented in more detail in the above-mentioned work, but we will deal with the interpretation of intercultural education presented in the Council of Europe in 1990 under the project "Democracy, Human Rights, Minorities: Education and Cultural aspects" (Portera, 2008). However, there is currently no single interpretation of intercultural education and no universal values. But it is worth mentioning certain principles that underpin the concept of intercultural education and which are taken as a basis: respect, peace, justice, environmental protection, human dignity, autonomy, etc. The intercultural education movement is very powerful in Europe, and one can confirm, taking into account many documents of Council of Europe, that intercultural education is a teaching about how we perceive other people who significantly differ from us.

If we take into account the chronology of European trends in education policy regarding intercultural education, the following documents of Council of Europe should be cited: "The New Challenges of Intercultural Education: Religious Diversity and Dialogue in Europe" (2002), Declaration of the European Ministries of Education on Intercultural Education in a New European Context (2003). These documents are interconnected in such a way that 
projects aimed at exploring other cultures, policies, and practices for teaching socio-cultural diversity were created thanks to them.

Social cohesion, as the efficiency index of a community, city and nation development strategy, is the result of the interaction of different nations and subcultures. That is why intercultural competences and relevant skills form a key element of intercultural education. Intercultural dialogue should be promoted internationally and should be seen as a tool to strike a balance between cultural diversity and social cohesion.

The Guideline on Intercultural Education clarified key concepts as follows:

- Culture in comprehensive aspect and dynamic aspect (Brotto et al., $2012: 22$ ), that in combination create the basis for educational context for educators and learners, policymakers and influencers, mass media representatives and community. The learning of intercultural competence is required for those who deal with foreigners, migrants, national minorities and representatives of other nations in general. At the same time, the intercultural competence is needed to be learnt by the migrants and newcomers to facilitate their social adaptation to the host community.

- Diversity is another important element of international education, as it's embedded in the educational setting. Interculturalism includes a better understanding of different cultures, as well as own culture considering that culture is a result of incorporating of the different cultures.

- Other aspects worth mentioning are social inclusion, challenging existing stereotypes, language training (Brotto et al., 2012).

The same document (Brotto et al., 2012) identified the intercultural education profile as a set of the following activities: cross-fertilisation, cultural relativism, multiple identities, diversity/pluralism, interaction, and revolutionary ideas - new collective identities (European citizenship, global citizenship) and cultural hybridization. Here we should comment on two more activities: ecumenical or interfaith dialogue that should take place among the communities across the religious, that will create a new beginning for the tolerance, and that is possible through another activity - co-operative learning. However, there is no individual learning per se, because the knowledge transfer considers at least two parties - a teacher and receiver, so any effective learning is cooperative. As a part of intercultural education, it should be more specific and more comprehensive in terms of types and forms of cooperation in learning.

The Council of Europe has proposed a system of strategic solutions, called the Intercultural Strategy, which has integrated cities into a network of intercultural cities, as a solution to the stated problems. This idea originated in 2004 (Council of Europe, 2018) and involved researchers, educators and civil servants in the decision-making system for creating intercultural cities, the main idea of which is to embrace diversity as a source of innovation, creativity, and entrepreneurship (Council of Europe, 2018).

Sumy currently joined the network of intercultural cities (in 2016), but there is a need to develop an intercultural development strategy as a document that will be a starting point to form appropriate commitments for the city and local government.

\section{CONCLUSIONS}

The globalization of world markets activates migration processes, namely the relocation of human resources in accordance with favourable conditions for development. These processes took place after the war, after the financial crises, after adverse political transformations. Another migration scenario is the search for educational opportunities and empowerment for academic mobility. The problems regarding the concentration of migrants around innovation clusters in Europe, the US and Asia require a deep study. This research focuses on the problems of migrants and national minorities who are in the community that is not ready for 
social inclusion. The isolation of migrants from the decision-making system in society leads to conflicts, discrimination, and as a consequence, to possible losses from the economic isolation of migrants from existing economic transactions. The Urban Development Strategy now foresees the development of an intercultural component that, with effective and clear formalization, provides economic and social benefits, including the growth of innovation and entrepreneurial activity.

We believe that the next step will be to formalize the intercultural development strategy of the city and to implement it further in order to improve the reputation, attractiveness and infrastructure of the city.

\section{REFERENCE LIST}

1. Adelman, C. (1993). Kurt Lewin and the origins of action research. Educational action research, 1(1), 7 24

2. Ansoff, H. I., \& Leontiades, J. C. (1976). Strategic portfolio management. Journal of General Management, 4(1), 13-29.

3. Barrett, M. (2013). Intercultural competence: A distinctive hallmark of interculturalism. Interculturalism and multiculturalism: Similarities and differences, 147-168.

4. Barrett, M. D., Huber, J., \& Reynolds, C. (2014). Developing intercultural competence through education. Strasbourg: Council of Europe Publishing. Available at: http://www.academia.edu/download/31096123/DICE.pdf

5. Brotto, F., Huber, J., Karwacka-Vogele, K., Nenuer, G., Ruffino, R., Teutsch, R. (2012). The dimensions of intercultural education. Edited by Jisef Huber. Intercultural competence for all. Preparation for living in a heterogeneous world, 11-50. Available at: https://www.coe.int/t/dg4/education/pestalozzi/source/documentation/pestalozzi2_en.pdf\#page=12

6. Council of Europe (2002). The new challenge of intercultural education: Religious diversity and dialogue in Europe. Available at: www.theewc.org/content/download/file/Religious_diversity

7. Council of Europe (2008). White Paper on Intercultural Dialogue (Strasbourg, Council of Europe Ministers of Foreign Affairs). Available at: www.coe.int, intercultural, source, white paper_final_revised_en

8. Council of Europe (2018). The origins of the intercultural city concept. Available at: https://www.coe.int/en/web/interculturalcities/origins-of-the-intercultural-concept

9. Declaration by the European Ministers of Education on intercultural education in the new European context (2003). Available at: rm.coe.int/declaration-by-the-european-ministers-of-education-on-i...

10. European Convention on Human Rights (2013). Council of Europe. Available at: www.echr.coe.int/Documents/Convention_ENG

11. European Union (2008). Green Paper on Migration \& Mobility: challenges and opportunities for EU education systems (Brussels, Commission of the European Communities), 4-7.

12. Portera, A. (2008). Intercultural education in Europe: epistemological and semantic aspects. Intercultural education, 19(6), 481-491.

13. Shvindina, H. (2016). The depopulation in Ukraine: Trapped in mortality crisis. In Forum Scientiae Oeconomia (Vol. 4, No. 1, pp. 5-19).

14. Tucker, J.A. (October 15, 2017). How Much Homogeneity Does Society Need? Foundation of Economic Education. Available at: https://fee.org/articles/how-much-homogeneity-does-society-need/ 